\title{
BALANCE OF SALTS AND GROWTH OF PAPAYA CULTIVARS IRRIGATED WITH SALINE WATER
}

\author{
BALANÇO DE SAIS E CRESCIMENTO DE CULTIVARES DE MAMOEIRO \\ IRRIGADAS COM ÁGUA SALINA
}

\section{Francisco Vanies da Silva SÁ ${ }^{1}$; Marcos Eric Barbosa BRITO²; Rômulo Carantino Lucena MOREIRA ${ }^{3}$; Alberto Soares de MELO ${ }^{4}$; Luderlândio de Andrade SILVA ${ }^{5}$; Hans Raj GHEYI ${ }^{6}$; Lizaiane Cardoso de FIGUEIREDO; Emanoela Pereira de PAIVA ${ }^{7}$}

1. Doutorando em Engenharia Agrícola, Universidade Federal de Campina Grande - UFCG, Campina Grande, PB, Brasil. vanies_agronomia@hotmail.com; 2. Professor, Doutor, Universidade Federal de Campina Grande - UFCG, Pombal, PB, Brasil; 3. Mestrando em Sistemas Agroindustriais - UFCG, Campina Grande, PB, Brasil; 4. Professor, Doutor, Universidade Estadual da Paraíba - UEPB, Campina Grande, PB, Brasil; 5. Mestrando em Horticultura Tropical - UFCG, Campina Grande, PB, Brasil; 6. Professor Visitante, Doutor, Universidade Federal do Recôncavo Baiano - UFRB, Cruz das Almas, PB, Brasil; 7. Doutorando em Fitotecnia, Universidade Federal Rural do Semi-Árido - UFERSA, Mossoró, RN, Brasil.

\begin{abstract}
The papaya crop has great socio-economic expression in the Brazil and is mainly grown in the northeastern region, which is facing serious problems of water shortage, particularly in its qualitative aspect, due to high concentration of salts in water. For best performance of a crop it is necessary to adopt managements strategies, such as the use of tolerant cultivars, thus, aimed to assess the balance of salts in the substrate, growth and partition of biomass of varieties of papaya irrigated with saline water. The experiment was conducted in a randomized complete block design with treatments arranged in a $2 \times 4$ factorial arrangement, consisting of two cultivars of papaya (Sunrise Solo and Tainung - 01) and four levels of water salinity $\left(1.2,2.4,3.6\right.$ and $\left.4.8 \mathrm{dS} \mathrm{m}^{-1}\right)$ with three replications. The balance of salts in the substrate, growth rate and the dry matter partitioning were evaluated to determine crops' tolerance to salinity in the initial growth phase. The water salinity increased linearly electrical conductivity, sodium absorption ratio and exchangeable sodium percentage of the substrate, and reduced growth and the biomass of varieties of papaya, in which reductions in biomass accumulation followed the order leaves $>$ roots $>$ stem. Salinity reduced the percentage of dry weight of stem and leaves and increased the dry weight of roots.
\end{abstract}

KEYWORDS: Carica papaya L. Threshold Salinity. Development.

\section{INTRODUCTION}

In irrigated fruit crops it is necessary to prevent the salinization process, particularly when the water used in irrigation has high concentrations of salts, emphasizing that fruits are considered sensitive and Brazil ranks third in world fruit production (AGRIANUAL, 2011), since salts can limit the growth, development and production of agricultural crops (AYERS; WESTCOT, 1999), especially in those of greater economic expression, such as the papaya (Carica papaya L.), considering that the Brazil is the $2^{\text {nd }}$ greatest producer of papaya fruit (AGRIANUAL, 2011).

Papaya is cultivated in almost all Brazilian territory; the main producing states being Bahia, Espírito Santo, Rio Grande do Norte and Ceará with $902,000630,000106,000$ and 100,000 tons, respectively. In addition to the vast economic potential, the crop still has great food importance in the diet of Brazilians to furnish calcium, provitamin $\mathrm{A}$ and vitamin $\mathrm{C}$ (ascorbic acid) (SERRANO; CATTANEO, 2010).
However, irrigated agriculture in semiarid climatic conditions, where mainly papaya crop is cultivated, faces problems with lack of water resources both quantitatively as well as qualitatively (MEDEIROS et al., 2003). However, the latter is shown to be more limiting, especially with regard to the presence of salts in the water, limiting its use in agricultural activities, since routinely these waters achieve electrical conductivity around $5.0 \mathrm{dS} \mathrm{m}{ }^{-1}$ (CAVALCANTE et al., 2005), and most crops do not tolerate soil salinity higher than $4.0 \mathrm{dS} \mathrm{m}^{-1}$ in the saturation extract (RICHARDS, 1954; AYERS; WESTCOT, 1999), triggering the search for resistant materials.

However, the identification of tolerant materials is not easy; due to the tolerance to salinity depends on numerous factors such as species, cultivar, growth stage, the characteristics of salts, intensity and duration of salinity stress, irrigation and soil management and metereological conditions (ASHRAF; HARRIS, 2004). Therefore, besides studying the species' morphological behavior, it is necessary to study the nature and intensity of stress 
Balance of salts...

in plants, as some crops can produce satisfactorily even under high salinity conditions (AYERS; WESTCOT, 1999).

Thus, the objective of this study was to evaluate balance of salts in the substrate, growth and partition of biomass of varieties of papaya irrigated with saline water.

\section{MATERIAL AND METHODS}

The experiment was conducted in a greenhouse at the Center for Science and Agrifood Technology - Universidade Federal de Campina Grande (CCTA-UFCG), Pombal, PB.

The experimental design consisted of a randomized block in factorial arrangement $(4 \times 2)$; four salt concentration in the irrigation water were
SÁ, F. V. S. et al.

evaluated based on electrical conductivity of water $(\mathrm{ECw})\left(\mathrm{SC}=1.2,2.4,3.6\right.$ and $\left.4.8 \mathrm{dS} \mathrm{m}^{-1}\right)$ and two cultivars (C) of papaya (Sunrise Solo and Tainung 01 ) with three repetitions and a total of twenty-four experimental units and each unit consisted of six plants.

The cultivation was performed in plastic tubes of $0.3 \mathrm{dm}^{3}$ in capacity, washed with $10 \%$ sodium hypochlorite containing a substrate consisting of a blend of vegetable soil, sand and cattle manure in the proportion of 2:1:1 based on volume, respectively. The chemical characteristics of substrate are described in Table 1. Seeds were sown at a rate of three seeds per tube and 30 days after full emergence of seedlings, thinning was carried out keeping only one plant in each container.

Table 1. Chemical characteristics of the soil and manure used to prepare substrate for the production of papaya seedlings irrigated with saline water.

\begin{tabular}{|c|c|c|c|c|c|c|c|c|c|c|c|c|}
\hline & EC & $\mathrm{pH}$ & $P$ & $\mathrm{~K}^{+}$ & $\mathrm{Ca}^{2+}$ & $\mathrm{Mg}^{2+}$ & $\mathrm{Na}^{+}$ & $\mathrm{Al}^{3+}$ & $\mathrm{H}^{+}+\mathrm{Al}^{3+}$ & CEC & ESP & $\mathrm{OM}$ \\
\hline & $\mathrm{dS} \mathrm{m}^{-1}$ & $\mathrm{CaCl}_{2}$ & $\mathrm{mg} \mathrm{dm^{-3 }}$ & & & & - & $\mathrm{ol}_{\mathrm{c}} \mathrm{dm}$ & & -1 & $-\%$ & $\mathrm{~g} \mathrm{~kg}^{-1}$ \\
\hline S & 0.06 & 6.55 & 11 & 0.51 & 3.55 & 3.15 & 0.29 & 0.00 & 0.66 & 7.87 & 3.68 & 9 \\
\hline M & 4.26 & 7.75 & 264.0 & 14.64 & 5.70 & 11.90 & 6.18 & 0.00 & 0.00 & 38.42 & 16.08 & 385 \\
\hline
\end{tabular}

$\mathrm{S}=$ Soil; M= Manure; P, K, Na: extractor Mehlich1; Al, Ca, Mg: extractor $\mathrm{KCl} \mathrm{1,0} \mathrm{mol} \mathrm{L}{ }^{-1} ; \mathrm{H}+\mathrm{Al}$ : extractor Calcium Acetate 0,5 mol $\mathrm{L}^{-1}$, pH 7,0; CEC: Sum of exchangeable cations; OM: Organic matter determined by Wet digestion - Walkley-Black method; ESP: Exchangeable sodium percentage.

Irrigations were daily performed in order to bring the soil close to the maximum holding capacity, based on the method of drainage lysimetry, and in the applied water depth was added a leaching fraction (LF) of $20 \%$. The volume applied (Va) in each pot was obtained by the difference between the previously applied water depth (La) minus the mean drainage [total volume drained (d) in a given treatment divided by the number of pots $(\mathrm{n})]$, as shown in equation 1 :

$V a=\frac{L a-(d / n)}{(1-L F)}$

Eq 1

The irrigation waters were prepared so as to have an equivalent ratio of $7: 2: 1$, among $\mathrm{Na}: \mathrm{Ca}$ : $\mathrm{Mg}$, respectively, using $\mathrm{NaCl}, \mathrm{CaCl}_{2} \cdot 2 \mathrm{H}_{2} \mathrm{O}$ and $\mathrm{MgCl}_{2} \cdot 6 \mathrm{H}_{2} \mathrm{O}$ salts, ion ratio predominantly found in water sources used for irrigation in small farms of Brazilian Northeast (MEDEIROS et al., 2003).

Following the methodology proposed by Benincasa (2003), the absolute and relative growth rates in height (AGRH and RGRH) - equations 2 and 3 - and stem diameter (AGRSD and RGRSD) equations 4 and 5, and number of leaves (AGRNL and RGRSD) equations 6 and 7, were determined based on the growth in stem diameter, height and production of leaves of papaya cultivars, observed 30 days after sowing when total plant emergence was obtained and the last growth analysis performed at 45 days after sowing.

$$
\begin{array}{ll}
A G R H=\frac{h 2-h 1}{t 2-t 1} & \text { Eq.2 } \\
R G R H=\frac{\ln _{n 2}-\ln h 1}{t 2-t 1} & \text { Eq.3 }
\end{array}
$$

where: AGRH $=$ absolute growth rate in plant height $\left(\mathrm{cm} \mathrm{day}^{-1}\right) ; \mathrm{h} 1=$ plant height $(\mathrm{cm})$ at time $\mathrm{t} 1 ; \mathrm{h} 2=$ plant height $(\mathrm{cm})$ at time $\mathrm{t} 2 ; \mathrm{RGRH}=$ relative growth rate in plant height $\left(\mathrm{cm} \mathrm{cm}^{-1}\right.$ day $\left.^{-1}\right) ; \mathrm{ln}=$ natural logarithm.

$$
\begin{array}{ll}
A G R S D=\frac{s d 2-s d 1}{t 2-t 1} & \text { Eq.4 } \\
\text { RGRSD }=\frac{\ln s d 2-\ln s d 1}{t 2-t 1} & \text { Eq.5 }
\end{array}
$$

where: AGRSD $=$ absolute growth rate in stem diameter $\left(\mathrm{mm} \mathrm{day}^{-1}\right)$; sd $1=$ plant stem diameter $(\mathrm{mm})$ at time $\mathrm{t} 1 ; \mathrm{sd} 2=$ plant stem diameter $(\mathrm{mm})$ at time $\mathrm{t} 2 ; \mathrm{RGRSD}=$ relative growth rate in stem diameter $\left(\mathrm{mm} \mathrm{mm}^{-1}\right.$ day $\left.^{-1}\right) ; \mathrm{ln}=$ natural logarithm.

$$
\begin{array}{ll}
A G R N L=\frac{n l 2-n l 1}{t 2-t 1} & \text { Eq.6 } \\
R G R N L=\frac{m n 2-\ln n ! 1}{t 2-t 1} & \text { Eq.7 }
\end{array}
$$


where: AGRNL = absolute growth rate in number of leaves (leaves day ${ }^{-1}$ ); nl1 = number of leaves at time $\mathrm{t} 1 ; \mathrm{nl} 2=$ number of leaves at time $\mathrm{t} 2 ; \mathrm{RGRNL}=$ relative growth rate in number of leaves (leaf-leaf ${ }^{-1}$ day $\left.^{-1}\right) ; \ln =$ natural logarithm.

Also, plants were collected at 45 days to obtain the dry mass of leaves (LDM), stem (SDM), roots (RDM), papaya plants were collected and leaves, stem and roots were separated, and later dried in a forced-air oven at $65^{\circ} \mathrm{C}$ for $72 \mathrm{~h}$ and weighed on an analytical scale.

Also, the salt balance in the substrate was evaluated at 45 days after sowing determining electrical conductivity of the saturation extract (ECse), pH and concentration of soluble sodium $(\mathrm{Na})$, calcium + magnesium $(\mathrm{Ca}+\mathrm{Mg})$ using the methodology recommended by Embrapa (2009), which is adopted by the Laboratory of Soil and Plants Nutrition CCTA/UFCG. With these data, sodium absorption ratio (SAR) and exchangeable sodium percentage (ESP) were determined according to the methodology of Richards (1954) described in equations 8 and 9 .

$$
S A R=\frac{N a}{\sqrt{\frac{(C a+M g)}{2}}} \quad \text { Eq. } 8
$$

A
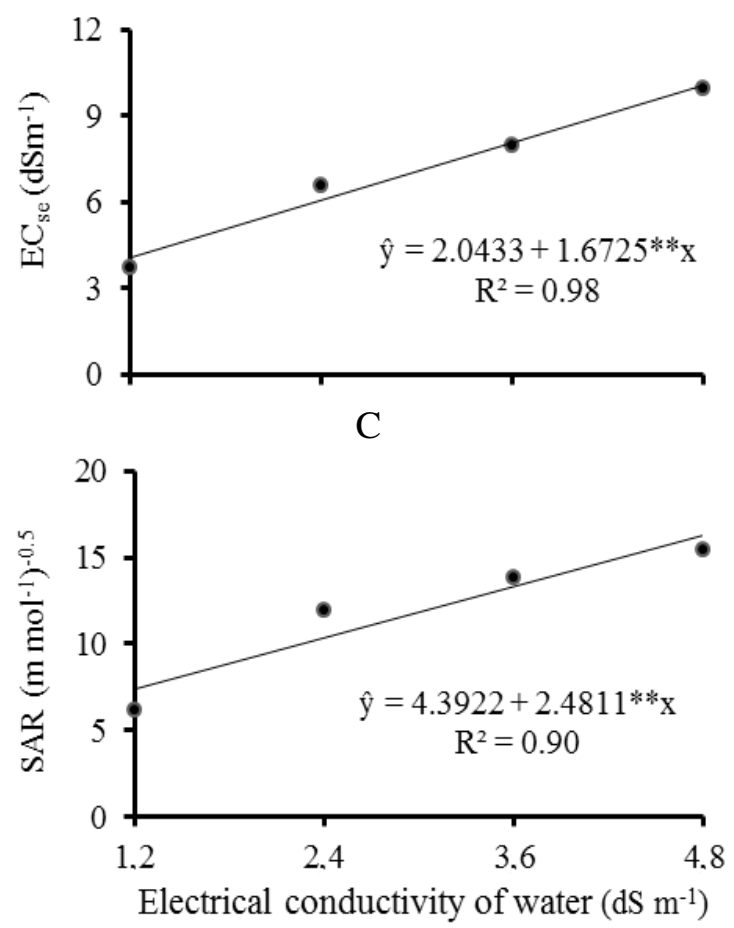

$E S P=\frac{100(0.01475 \mathrm{RAS}-0.0126)}{1+(0.01475 \mathrm{RAS}-0.0126)}$

Data were evaluated by analysis of variance through the ' $F$ ' test. In case of significance, the means of cultivars of papaya were compared by Tukey's test at 0.05 probability and for the water salinity factor regression analysis was performed using the software SISVAR (FERREIRA, 2011).

\section{RESULTS AND DISCUSSION}

A significant influence was observed only for the factor salinity levels of irrigation water on the variables electrical conductivity of saturation extract, $\mathrm{pH}$, sodium absorption ratio (SAR) and exchangeable sodium percentage (ESP) at 0.01 probability level (Fugure1). These results indicate that irrigation with increasing water salinity directly influenced the salinity and sodicity parameters of substrate. Significant changes due to salinity of irrigation water on substrate salinity were observed by Rebique et al. (2009) while studying the production of lemon clove seedlings under different levels of irrigation water salinity.

B
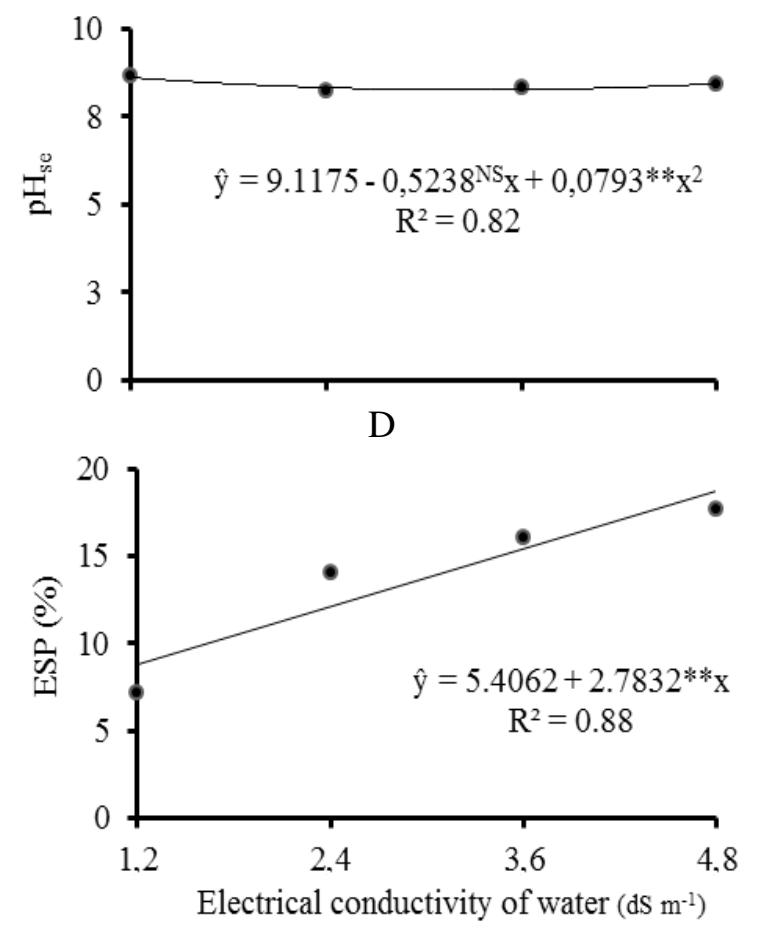

Figure 1. Electrical conductivity $-\mathrm{EC}_{\mathrm{se}}(\mathrm{A}), \mathrm{pH}_{\mathrm{se}}(\mathrm{B})$, sodium absorption ratio - $\mathrm{SAR}(\mathrm{C})$ and exchangeable sodium percentage - ESP (D) of substrate irrigated with different levels of water salinity and planted with two cultivars of papaya. 
In general, increase in water salinity linearly incremented electrical conductivity of saturation extract, sodium absorption ratio and exchangeable sodium percentage of the substrate independent of the papaya cultivar studied (Figure $1 \mathrm{~A}, \mathrm{C}$ and D). With unit increase in irrigation water salinity, there was an increase of $\left.1.67(\mathrm{dS} \mathrm{m})^{-1}\right), 2.48\left(\mathrm{~m} \mathrm{~mol}^{-1}\right)^{-0.5}$ and $2.78 \%$ for electrical conductivity of saturation extract, sodium absorption ratio and exchangeable sodium percentage, respectively. The increase in salinity and sodicity in the substrate as a function of irrigation water salinity was also observed by Rebique et al. (2009) while studying the production of seedlings of lemon and by Cavalcante et al. (2010) in papaya seedlings. The authors observed that increase in salinity and sodicity reduced growth and biomass accumulation of seedlings of lemon and papaya, compromissing the production of good quality seedlings.

Regarding the $\mathrm{pH}$ of substrate, a quadratic response was observed as a function of the irrigation water salinity levels decreasing up to $\mathrm{ECw}=3.3 \mathrm{dS}$ $\mathrm{m}^{-1}$ and increasing thereafter (Figure 1B). The little reduction observed in $\mathrm{pH}$ may be related to leaching efficiency up to the $\mathrm{ECw}$ of $3.3 \mathrm{dS} \mathrm{m} \mathrm{m}^{-1}$, also associated with the decomposition of maure present in the substrate and release of humic substances thereby reducing soil alkalinity (Nunes et al., 2009), as well as due to the presence of calcium salts, which even being neutral in alkalinity, has shown promising results in the recovery of soil degraded by sodium salts (SA et al., 2013).

Significant influence of irrigation water salinity levels was observed on the absolute growth rates of height, stem diameter, leaf number and

A

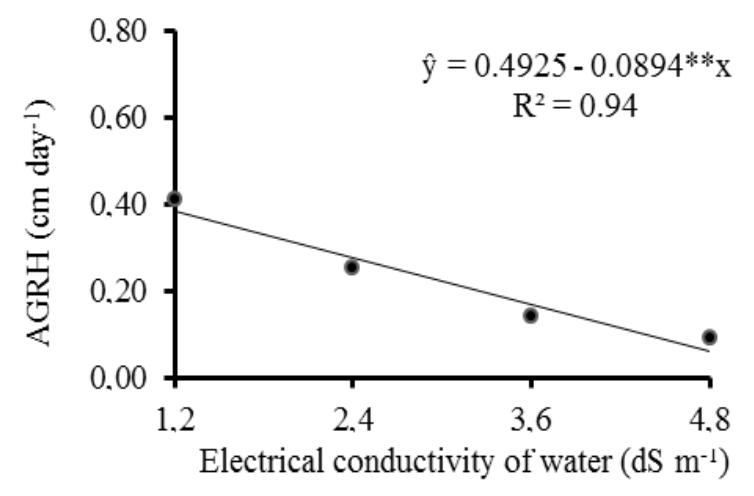

relative growth rate of height at 0.01 probability level (Figure 2). For the relative growth rate of stem diameter, only a significant effect was observed for the cultivars at 0.01 probability level (Figure 2). However, the relative growth rate of the number of leaves did not show significant influence $(\mathrm{p}>0.05)$ (Figure 3). Changes in vegetative growth of papaya seedlings under saline conditions were also verified by Cavalcante et al. (2010), studying different sources of saline water in the production of seedlings of papaya cultivar Sunrise Solo.

There were linear reductions in absolute growth rates of stem diameter and height and for the relative growth rate in height due to increased irrigation water salinity (Figure $2 \mathrm{~A}, \mathrm{~B}$ and $\mathrm{C}$ ). Reductions in height and diameter growth depending on salinity levels compromise the obtention of healthy papaya seedlings by delaying the acheivement of the ideal height for seedling transplanting, which is around $15 \mathrm{~cm}$ (MANICA, 2006). Reductions in stem diameter influence the carrying and conducting capacity of sap flow, decrease the vigor of the plants and consequently leaving it sensitive to the environmental conditions. It is believed that reductions in growth of papaya cultivars can be related to the toxicity by specific ions, especially sodium, since appreciable increase in SAR and ESP were observed under higher salinity of irrigation water. According to Flowers and Flowers (2005), salinity promotes physiological disorders, promoting toxicity to crops triggered mainly by sodium ions, affecting the growth negatively and thereby the accumulation of biomass by crops (Figure 2 and 4 ).

B

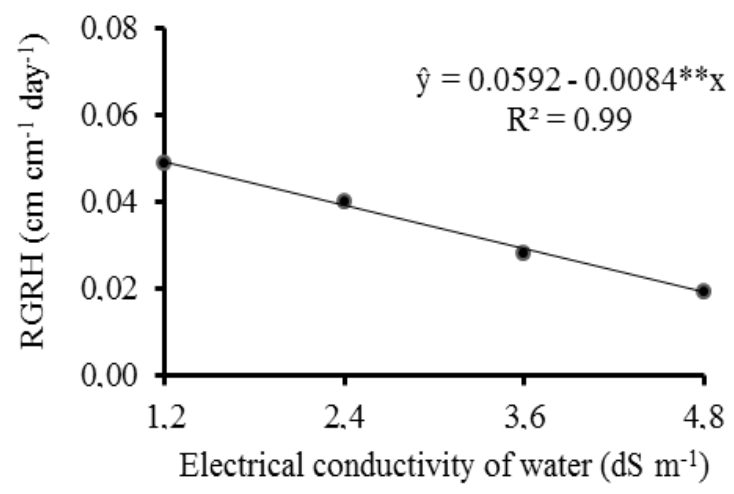


Balance of salts...

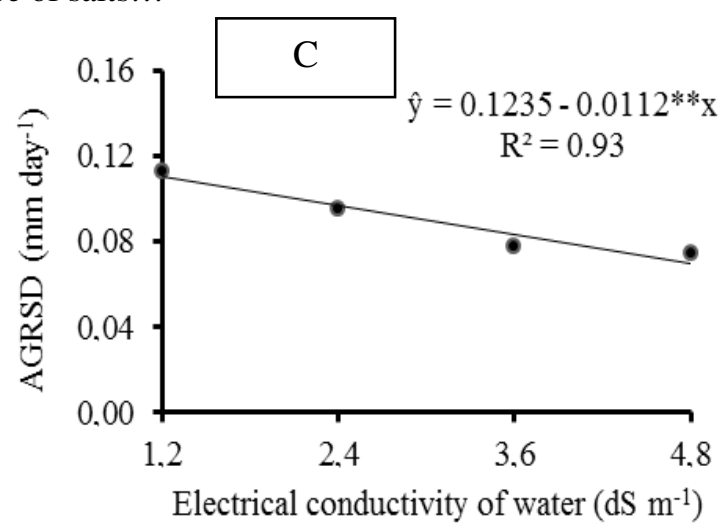

SÁ, F. V. S. et al.

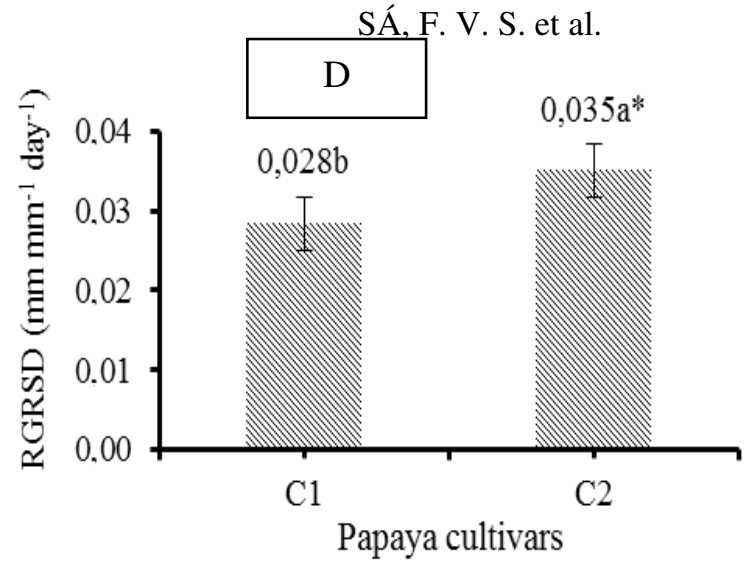

Figure 2. Mean absolute and relative growth rates in height (A, B), and absolute growth rates in stem diameter (C) of papaya cultivars as a function of irrigation water salinity and relative growth rate in stem diameter (D) of papaya cultivars (C1 - Sunrise Solo and C2 - Tainung - 01) grown under different irrigation water salinity levels.

Regarding the relative growth rate in stem diameter, it is observed that Tainung - 01 cultivar (C2) had the higher stem diameter (Figure 2 D). This result may be related to specie's own growth habit, given that papaya cultivars belonging to the Formosa group, to which this cultivar belongs, mostly reach sizes larger than cultivars of Solo group, in which $\mathrm{C} 1$ is inserted, thereby requiring a higher stem diameter growth rate to sustain the development of the plant.

As to the absolute growth rate of the number of leaves, linear reductions of the order of $10.83 \%$ with unit increase in irrigation water salinity were observed (Figure 3). Considering that leaves are responsible for $90 \%$ of the carbohydrates synthesized by the plant (BENICASA, 2003), reductions in leaf production directly imply a reduction in vegetative growth and biomass accumulation of plants. This fact was verified in this study, considering that the increase in water salinity reduced the rate of leaf production as well as a smaller plant height, stem diameter and biomass formation of papaya cultivars (Figures 1, 2, 3 and 4). Reduction in the formation of leaves in frut trees under salt stress have also been verified in acerola (Gurgel et al., 2007), citric rootstocks (Brito et al., 2014), and papaya (Cavalcante et al., 2010).

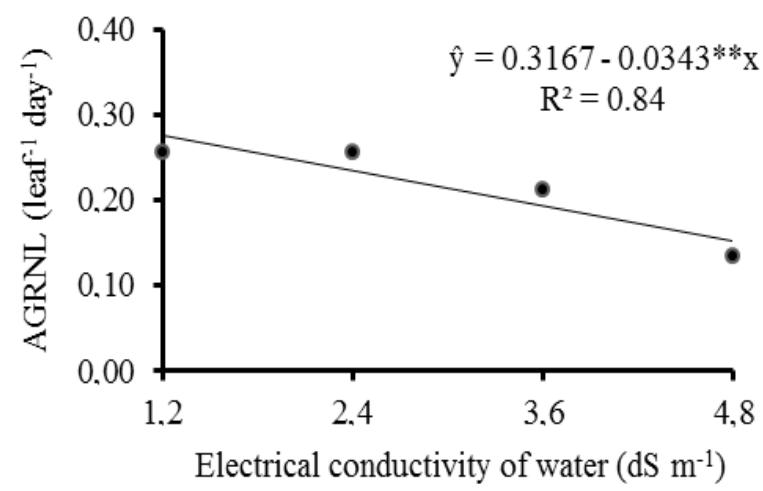

Figure 3. Absolute growth rate of number of leaves (AGRNL) of papaya cultivars under different levels of irrigation water salinity.

For biomass variables, only an isolated effect of salinity of irrigation water was observed at 0.01 probability level (Figure 4). Significant changes in biomass accumulation in plants under salinity induced by irrigation water were also verified by Brito et al. (2008) and Fernandes et al.
(2012) in the production of citrus rootstocks and Cavalcante et al. (2010) in papaya seedlings.

Figure 4 shows that the biomass accumulation of papaya cultivars was drastically reduced by increase in salinity of irrigation water. The dry mass of leaves was the most affected with increase in water salinity, considering that the unit increase in water 
salinity, proportionated decrease of $0,0531,0,0267$ and $0,0358 \mathrm{~g}$ in dry mass of leaf, stem and root, respectively (Figures $4 \mathrm{~A}, \mathrm{~B}$ and $\mathrm{C}$ ), indicating that the salinity of the substrate reached prejudicial levels to the crop, reducing the accumulation of dry matter (Figure 1). Reductions in biomass

A

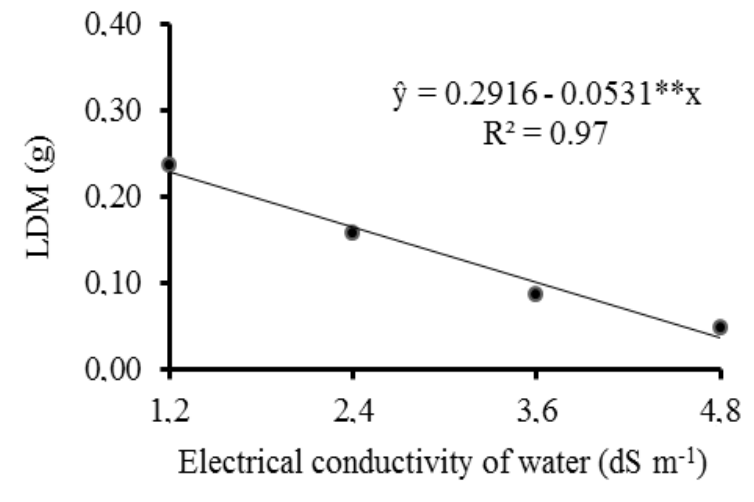

C

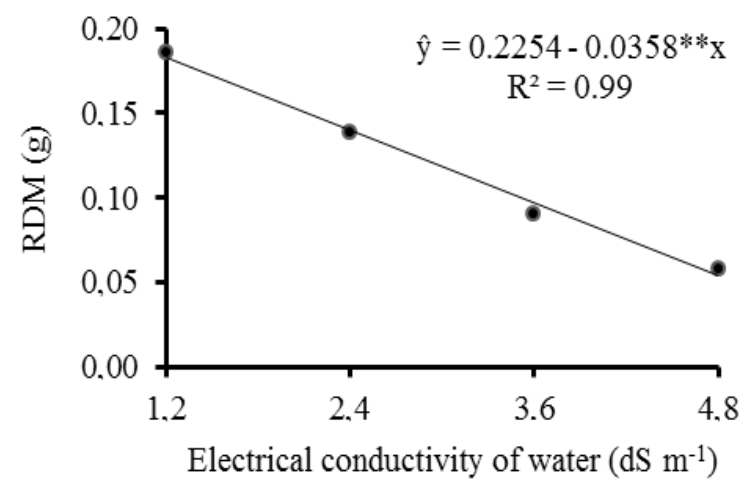

SÁ, F. V. S. et al.

accumulation due to the increase in irrigation water salinity were verified by Gurgel et al. (2007) in acerola; by Brito et al. (2008), Rebique et al. (2008) and Fernandes et al. (2011) in citrus; by Cavalcante et al. (2010) in papaya; and by Sousa et al. (2011) and Alves et al. (2013) in cashew.

B

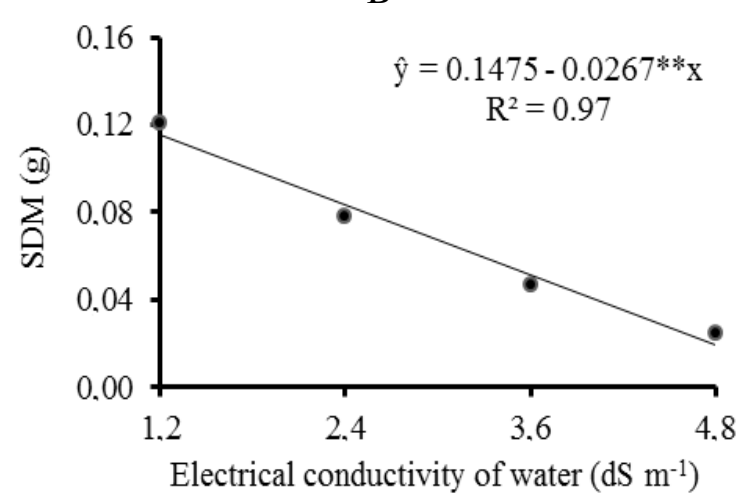

D

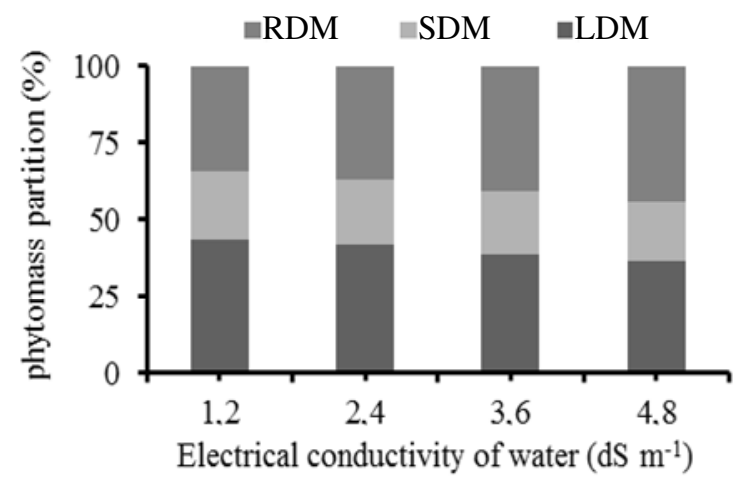

Figure 4. Dry mass of leaves (LDM) (A), stem (SDM) (B), roots (RDM) (C) and phytomass partition (D) of papaya cultivars subjected to salinity levels of irrigation water.

It is observed, in the biomass partition, that the percentage of leaves decreased with increase in water salinity. An opposite effect was observed for the accumulation of dry biomass in roots, which increased its percentage with the increase in salinity of water while for the stems, there were only slight reductions due to the increase in salinity of irrigation water (Figure 4D).

The mechanism to reduce investment in biomass accumulation in leaves may be related to the mechanism of tolerance of papaya plants to salt stress, since decrease in the investment in leaves reduces the demand for transpiration of seedlings, thereby decresing water absorption and thus reducing the accumulation of toxic salts within the plant. A greater investment in root systems may also lead to the exploitation of a larger volume of soil, favoring absorption of water and essential elements, which are particularly important in soils with a limited ability to supply nutrients (Marschner, 2005), a fact commonly observed in saline and sodic soils, as observed in the higher salinity levels studied (Figure 1).

\section{CONCLUSION}

The increase in salinity linearly increased electrical conductivity of saturation extract, sodium absorption ratio and the percentage of exchangeable sodium in the substrate, which in turn reduces growth and biomass accumulation of papaya cultivars.

The decrease in biomass accumulation followed the order dry mass of leaves $>$ roots $>$ stem.

Increase in salinity altered the biomass partition of papaya plants, reducing the percentage of dry mass of stem and leaf, and increasing the percentage of root biomass. 
RESUMO: A cultura do mamoeiro exerce grande expressão socioeconômica no senário brasileiro, sendo principalmente cultivado na região nordeste do país, que enfrenta sérios problemas com escassez dos recursos hídricos, principalmente em seu aspecto qualitativo, verificando-se águas com elevados teores de sais. Para melhor desempenho da cultura é necessário a adoção de estratégias de manejos, a exemplo da utilização de cultivares tolerantes, com isso, objetivou-se avaliar o balanço de sais no substrato, o crescimento e a partição de fitomassa de cultivares de mamoeiro irrigadas com água salina. $\mathrm{O}$ experimento foi realizado em um delineamento experimental de blocos casualizados, com os tratamentos distribuídos em esquema fatorial 2 x 4, constituídos de duas cultivares de mamoeiro (Sunrise Solo e Tainung 01) e quatro níveis de salinidade da água $\left(1,2 ; 2,4 ; 3,6\right.$ e 4,8 dS m$\left.{ }^{-1}\right)$ com três repetições. O balanço de sais no substrato, à taxa de crescimento e a partição de fitomassa seca foram avaliados de modo a determinar a tolerância a salinidade pela cultura na fase inicial de crescimento. $\mathrm{O}$ aumento da salinidade da água aumentou linearmente a condutividade elétrica, a relação de absorção de sódio e a percentagem de sódio trocável do substrato, o que reduziu o crescimento e o acúmulo de fitomassa das cultivares de mamoeiro, em que as reduções no acúmulo fitomassa seguiram a ordem fitomassa seca da folha $>$ raízes $>$ caule . O aumento da salinidade reduziu o percentual de fitomassa seca do caule e das folhas e aumentou o de fitomassa das raízes.

PALAVRAS-CHAVE: Carica papaya L. Salinidade limiar. Desenvolvimento.

\section{REFERENCES}

AGRIANUAL: Anuário da agricultura Brasileira. São Paulo: FNP, 2011.

ALVES, F. A. L.; PONTE, L. F. A.; FERREIRA-SILVA, S. L.; MAIA, J. M.; SILVEIRA, J. A. G. Germinação e estabelecimento de plântulas de cajueiro-anão precoce (Anacardium occidentale L.) em função da salinidade.

Revista Brasileira de Ciências Agrárias, Recife, v. 8, n. 2, p. 197-204, 2013.

http://dx.doi.org/10.5039/agraria.v8i2a2062.

ASHRAF, M.; HARRIS, P. J. C. Potential biochemical indicators of salinity tolerance in plants. Plant Science, Limerick, v. 166, n. 1, p. 3-16, 2004. http://dx.doi.org/10.1016/j.plantsci.2003.10.024.

AYERS, R. S.; WESTCOT, D. W. Qualidade da água na agricultura. Campina Grande: UFPB, 1999. 153p. Estudos FAO: Irrigação e Drenagem, 29.

BENINCASA, M. M. P. Análise de crescimento de plantas: noções básicas. Jaboticabal: Funep, 2003. 41p.

BRITO, M. E. B.; FERNANDES, P.D.; GHEYI, H.R.; MELO, A.S.; SOARES FILHO, W.S.; SANTOS, R.T. Sensibilidade à salinidade de híbridos trifoliados e outros porta-enxertos de citros. Revista Caatinga, Mossoró, v. 27, n. 1, p.17-27, 2014.

BRITO, M. E. B.; FERNANDES, P. D.; GHEYI, H. R.; MELO, A. S. de; CARDOSO, J. A. F.; SOARES FILHO, W. S. Sensibilidade de variedades e híbridos de citrange à salinidade na formação de porta-enxertos. Revista Brasileira de Ciências Agrárias, Recife, v. 3, n. 4, p 343-353, 2008. http://dx.doi.org/10.5039/agraria.v3i4a364.

CAVALCANTE, L. F.; CORDEIRO, J. C.; NASCIMENTO, J. A. M. DO; CAVALCANTE, I. H. L.; DIAS, T. J. Fontes e níveis da salinidade da água na formação de mudas de mamoeiro cv. Sunrise solo. Semina: Ciências Agrárias, Londrina, v. 31, suplemento 1, p. 1281-1290, 2010. http://dx.doi.org/10.5433/16790359.2010v31n4Sup1p1281.

CAVALCANTI, M. L. F.; FERNANDES, P. D.; GHEYI, H. R.; BARROS JÚNIOR, G.; SOARES, F. A. L.; SIQUEIRA, E. C. Tolerância da mamoneira BRS 149 à salinidade: germinação e características de crescimento. Revista Brasileira de Engenharia Agrícola e Ambiental, Campina Grande, v. 9, suplemento, p. $57-61,2005$. 
EMPRESA BRASILEIRA DE PESQUISA AGROPECUÁRIA. Manual de análises químicas de solos, plantas e fertilizantes. 2.ed. ver. e amp. Brasília: Embrapa Informação Tecnológica, 2009. 628p.

FERNANDES, P. D.; BRITO, M. E. B.; GHEYI, H. R.; SOARES FILHO, W. S.; MELO, A. S. DE; CARNEIRO, P. T. Crescimento de híbridos e variedades porta-enxerto de citros sob salinidade. Acta Scientiarum Agronomy, Maringá, v. 33, n. 2, p. 259-267, 2011.

http://dx.doi.org/10.4025/actasciagron.v33i2.5582.

FERREIRA, D.F. Sisvar: a computer statistical analysis system. Ciência e Agrotecnologia, Lavras, v. 35, n. 6, p. 1039-1042, 2011. http://dx.doi.org/10.1590/S1413-70542011000600001.

FLOWERS, T. J.; FLOWERS, S. A. Why does salinity pose such a difficult problem for plant breeders? Agricultural Water Management, New York, v. 78, n. 4, p. 15-24, 2005.

http://dx.doi.org/10.1016/j.agwat.2005.04.015.

GURGEL, M. T.; FERNANDES, P. D.; GHEYI, H. R.; SANTOS, F. J. S.; BEZERRA, I. L. Uso de águas salinas na produção de mudas enxertadas de aceroleira. Revista Caatinga, Mossoró, v. 20, n. 2, p. 16- 23, 2007.

MAAS, E. V.; HOFFMAN, G. J. Crop salt tolerance - current assessment. Journal of Irrigation and Drainage Division of ASCE, New York, v. 103, n. 2, p. 115-134, 1977.

MANICA, I. Cultivares e melhoramentos. In: MANICA, I.; MARTINS, D. S.; VENTURA, J. A (Eds). Mamão: tecnologia de produção pós-colheita, exportação, mercados. Porto Alegre - RS: Cinco continentes, 2006. p. 49-82.

MARSCHNER, H. Mineral nutrition of higher plants. 2. ed. Orlando: Academic Press, 2005. 889 p.

MEDEIROS, J. F.; LISBOA, R. A.; OLIVEIRA, M.; SILVA JÚNIOR, M. J.; ALVES, L. P. Caracterização das águas subterrâneas usadas para irrigação na área produtora de melão da Chapada do Apodi. Revista Brasileira Engenharia Agrícola e Ambiental, Campina Grande, v.7, n. 3, p.469-472, 2003.

http://dx.doi.org/10.1590/S1415-43662003000300010.

NUNES, J. C.; CAVALCANTE, L. F.; REBEQUI, A. M.; LIMA NETO, J.; DINIZ, A.D.; SILVA, J.J.M.; BREHM, M.A.S. Formação de mudas de noni sob irrigação com águas salinas e biofertilizante bovino no solo. Revista de Engenharia Ambiental, Santo do Pinhal, v. 6, n. 2, p. 451-463, 2009.

REBEQUI, A. M.; CAVALCANTE, L. F.; NUNES, J. C.; DINIZ, A. A.; BREHM, M. A. S.; BECKMANNCAVALCANTE M. Z. Produção de mudas de limão cravo em substrato com biofertilizante bovino irrigado com águas salinas. Revista de Ciências Agrárias, Lisboa, v. 32, n. 2, p. 219-228, 2009.

RICHARDS, L. A. (ed.). Diagnosis and improvement of saline and alkali soils. Washington: United States Salinity Laboratory, 1954, 160p. USDA. Agriculture Handbook, 60.

SÁ, F. V. S.; ARAÚJO, J. L.; NOVAIS, M. C.; SILVA, A. P.; PEREIRA, F. H. F.; LOPES, K. P. Crescimento inicial de arbóreas nativas em solo salino-sódico do nordeste brasileiro tratado com corretivos. Revista Ceres, Viçosa, v. 60, n. 3, p. 388-396, 2013. http://dx.doi.org/10.1590/S0034-737X2013000300012.

SERRANO, L. A. L.; CATTANEO, L. F. O cultivo do mamoeiro no Brasil. Revista Brasileira de Fruticultura, Jaboticabal, v. 32, n. 3, p. 657-959, 2010. http://dx.doi.org/10.1590/S0100-29452010000300001.

SOUSA, A. B. O.; BEZERRA, M. A.; FARIAS, F. C. Germinação e desenvolvimento inicial de clones de cajueiro comum sob irrigação com água salina. Revista Brasileira de Engenharia Agrícola e Ambiental, Campina Grande, v. 15, n. 4, p. 390-394, 2011. http://dx.doi.org/10.1590/S1415-43662011000400010. 